Winter 2009

\title{
The Dollar, the Euro and the Role of Emerging Economies
}

\author{
Bala Batavia
}

Anastasios G. Malliaris

Loyola University Chicago, tmallia@luc.edu

Follow this and additional works at: https://ecommons.luc.edu/business_facpubs

Part of the Business Commons

\section{Author Manuscript}

This is a pre-publication author manuscript of the final, published article.

\section{Recommended Citation}

Batavia, Bala and Malliaris, Anastasios G.. The Dollar, the Euro and the Role of Emerging Economies. International Journal of Indian Culture and Business Management, 2, 1: 11-29, 2009. Retrieved from Loyola eCommons, School of Business: Faculty Publications and Other Works, http://dx.doi.org/10.1504/ IJICBM.2009.021595

This Article is brought to you for free and open access by the Faculty Publications and Other Works by Department at Loyola eCommons. It has been accepted for inclusion in School of Business: Faculty Publications and Other Works by an authorized administrator of Loyola eCommons. For more information, please contact ecommons@luc.edu.

\section{(c) $($ () $\ominus$}

This work is licensed under a Creative Commons Attribution-Noncommercial-No Derivative Works 3.0 License. (C) Inderscience 2009 . 


\title{
THE DOLLAR, THE EURO AND THE ROLE OF EMERGING CURRENCIES
}

\author{
Bala Batavia, DePaul University
}

A.G. Malliaris, Loyola University Chicago

\begin{abstract}
Since the collapse of the Bretton Woods Global International System in 1971, the world economy has experienced significant currency volatility. The major economies of the world have addressed such volatility differently. The EU has chosen to follow a monetary union and introduced successfully a new currency. The U.S. has paid less attention to the fluctuations of the dollar and has pursued an independent monetary policy to promote national economic stability. Japan has seen its currency appreciate significantly. This paper argues that while trade and growth across the globe are doing well, financial developments are intensifying the competition between the U.S. dollar and the euro. Four possible future scenarios are developed and discussed.
\end{abstract}

JEL Classification: F01, F31, F33

Keywords: International Monetary System, Global Currencies, Euro

Current Version: August 21, 2007 


\section{Introduction}

One of the best years in several decades for global GDP growth was 2004 when it rose slightly above 5 percent (see Figure 1). Most major parts of the world recorded improved growth performance. Similar growth continued during 2005 but at a slightly reduced pace. Despite the surging energy prices, prospects for 2006 remain favorable. Such growth is projected to fall from about 4.5 percent in 2005 to about 4 percent in 2006 as shown in Figure 1.

Figure 1: Global Outlook (Real GDP; percent change from four quarters earlier)

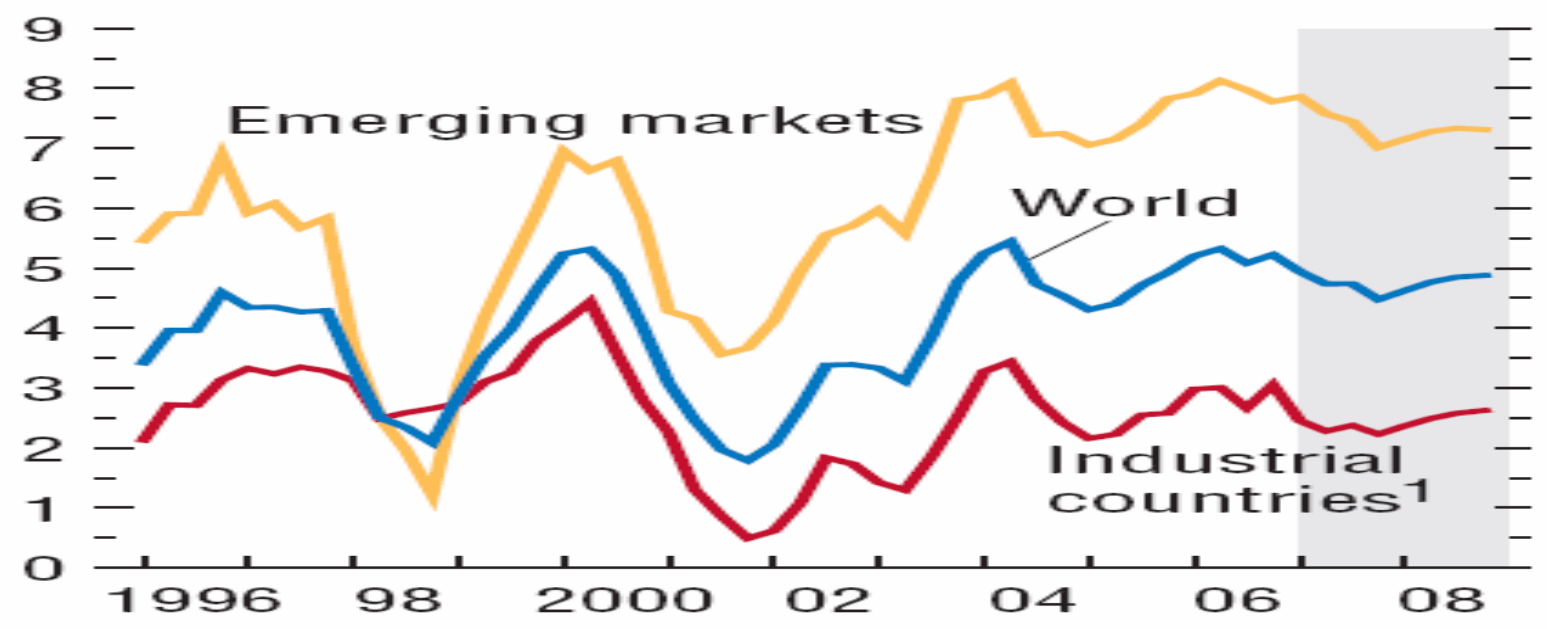

Source: World Economic Outlook (April 2007)

Global trade has also recovered strongly since the downturn in 2001 and continues to be an important engine of growth, as reported in the International Monetary Fund (2005). It is currently expanding at something close to twice the rate of growth of world GDP as illustrated in Figure 2. Reductions in inflation in many countries have greatly improved the prospects for sustained growth. The improvements in performance and, in many cases, economic policies have been substantial and significant. Japan recorded stronger performance in 2005 than we have seen for some years. Among the industrial economies, the Euro area was almost alone in continuing to grow at a lackluster pace.

In emerging and transition economies, there have been widespread improvements in economic growth. We have seen rapid growth not just in emerging Asia-including China and India-but in the transition economies of Europe, including Russia, the Ukraine and the new members of the EU-where growth performance has, so far, been largely unaffected by sluggish Euro area growth. In some emerging markets, real progress has been made in increasing the resilience of economies to withstand external shocks. 
Figure 2: Global Trade (SDR Terms; 3-Month Moving Average)

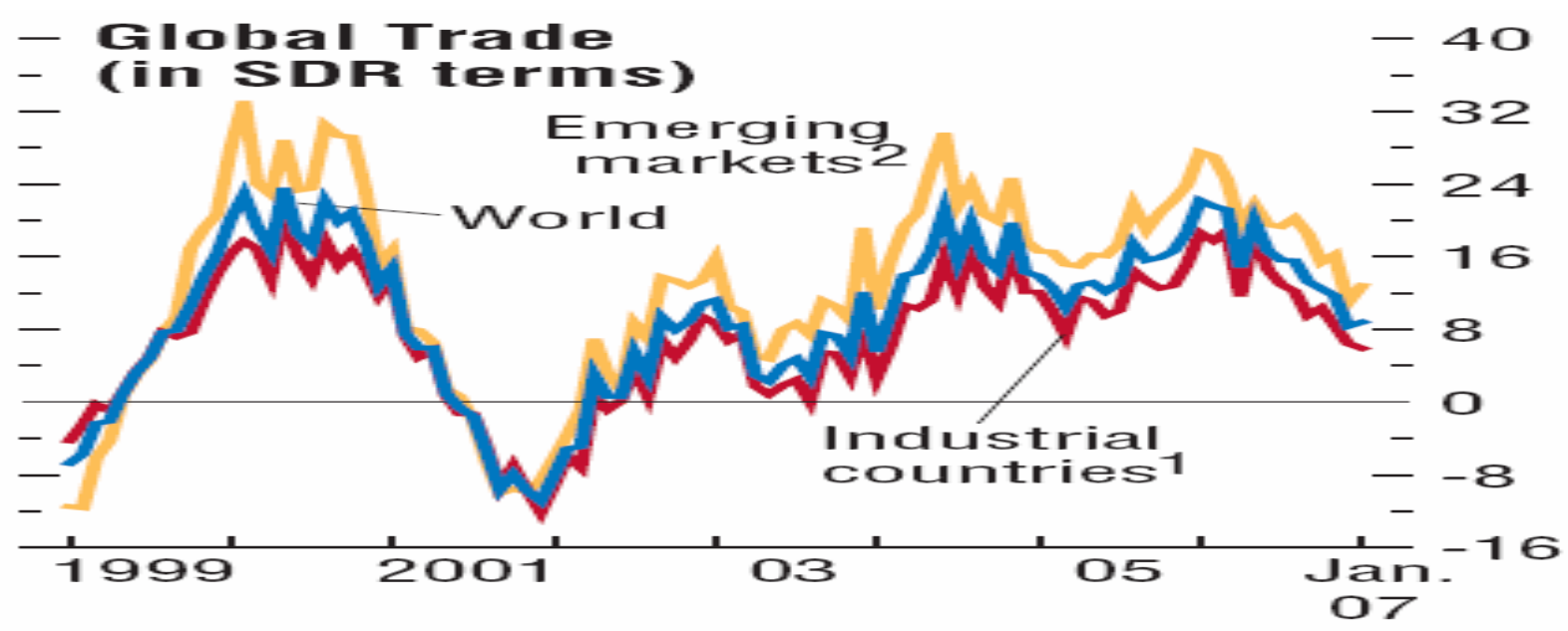

Source: World Economic Outlook (April 2007)

The U.S. economy continues to be the primary engine of global growth. In the global context, however, it is the American current account deficit that gives greater cause for concern. But the US deficit is only one manifestation of the current global payments imbalance. As discussed in Krueger (2005), the persistently weak growth performance of the Euro area is another factor contributing to the US current account deficit. More rapid growth in Europe would ease pressure on the global imbalances. Europe's growth prospects depend crucially on structural reforms that would lead to more flexible and responsive economies.

A more buoyant Japan would also help ease global payments imbalances. After a year of rapid growth to the middle of 2005, the economy has slowed in recent quarters - a result, in part, of a correction in the IT sector. But economic activity should firm over the course of 2005 thanks to much improved fundamentals. Over the medium term, however, further structural reforms will be needed to boost growth prospects at a time of rapid demographic change.

Debt levels rose during the last recession as governments struggled to offset some of the effects of the downturn. A significant reduction in debt levels is essential if debt sustainability is to be achieved over the medium and longer term; and if governments are to have any room for maneuver with counter-cyclical policy and successfully to reduce vulnerability to outside shocks and changes in the economic cycle.

\section{Global Financial Instability}

The positive recent economic fundamentals have contributed to the financial stability of the global monetary system. We may also recall that the Bretton Woods system had proved to be remarkably durable, adaptable and successful. In the period up to 1971 the system of fixed but adjustable exchange rates established as part of the postwar settlement provided a stable framework that fostered growth. The Fund's ability to provide its member countries with temporary financial support during balance of payments crises proved critical, on more than one occasion, to the maintenance of stability in the system as a whole. 
Nevertheless, the Asian crisis, and others in Russia, Argentina, Brazil and Turkey, taught us some valuable lessons. With hindsight, of course, it should have been more evident to many of those involved-including the IMF - that trouble was brewing for some of those countries. The proximate cause of the crisis in Asia was the sudden sharp reversal of capital flows away from the region. Net inflows to the Asian crisis countries were roughly 6.3 percent of their GDP in 1995, and 5.8 percent in 1996. In 1997, net outflows were 2 percent of GDP, a figure that rose to 5.2 percent the following year.

Asia's experience in the late 1990s reminded us of things we already knew, but whose importance we perhaps underestimated. Fixed exchange rates and the poor regulation of the banking and financial sector in many countries had enabled banks to build up liabilities in one currency and assets in another. Government assurances that exchange rate pegs would be sustained left currency mismatches unrecognized. Devaluation then left financial institutions facing massive losses, or insolvency. Once the cushion of foreign capital was removed, the weaknesses of domestic banking systems were revealed-as was the impact on economic performance. The Asian crisis also underlined that the benefits of short-term exchange rate stability are greatly outweighed by the risks that pegged or tightly managed exchange rate regimes bring - not least from the danger of currency mismatches in the corporate and the banking sectors. Fixed exchange rates can result in very large-and sudden - changes in the rate, thus creating great volatility and lost output over the longer term. The move to flexible exchange rates in most countries has reduced vulnerabilities. An overview of exchange rates is given in Fischer (2001) and a discussion of global instabilities can be found in Malliaris (2002) and Salvatore (2005).

To achieve a strong, well-regulated financial sector means addressing issues such as nonperforming loans, capital adequacy, and effective supervision. Financial institutions need the appropriate incentives to develop the skills required to assess and manage credit risk and returns. Effective bankruptcy laws - that strike the right balance between creditors' and debtors' rightsneed to be in place.

\section{The U.S. Trade Deficit}

In recent years, exports have grown faster than imports in China, resulting in an overall trade surplus. In other countries, including the United States, imports have grown faster than exports, resulting in an overall trade deficit. A large and continual trade deficit may also be troublesome to the extent that it increases U.S. reliance on international borrowing - the sale abroad of U.S. bonds and other securities. Also, China has emerged as a major source of U.S. imports, leading to a widespread view that the record overall U.S. trade deficits of recent years are "made in china.” In reality, China is the major player but other player also do affect U.S. traded deficit.

The U.S. merchandise trade deficit with China alone accounted for about $\$ 162$ billion in 2004 or nearly one-quarter of the total U.S. trade deficit, up from a minor share in the mid1980s. Figure 3 highlights the growing contribution of China to the overall deficit and the declining contribution of Japan over the same period. Coming at the same time as record overall trade deficits, the rapidly growing bilateral trade deficit with China has prompted calls for new barriers to U.S. 
China currently has the largest bilateral trade surplus with the United States; relative to the size of China's economy, the surplus is even larger. Analysts estimate that the U.S. current account deficit, now 6 percent of GDP, would need to drop to 2-3 percent of GDP in order to achieve long-run sustainability (Kouparitsas, 2005; Roubini and Setser, 2004). Thus, without reductions in other bilateral imbalances, sustainability could not be achieved even if the U.S.China trade deficit dropped to zero.

Chinese exports of textile and apparel products to the United States have continued to grow as a share of total U.S. imports at the industry level and as a share of U.S. domestic consumption.

Despite the recent emphasis on textiles and apparel, where U.S. imports from China soared in early 2005 following the elimination of U.S. quotas on these products, Chinese competition in other manufacturing industries has been growing even more rapidly.

As with textiles and apparel, to a large extent these Chinese gains have come at the cost of traditional exporters. The depreciation of the U.S. dollar relative to the euro and the Canadian dollar has reinforced this trend by redirecting U.S. import demand toward China, Japan, and other East Asian exporters.

Now, Chinese producers have proved to be experts at producing increasingly sophisticated products. Chinese auto parts are already entering the U.S. market in substantial quantities; imports of Chinese-built vehicles are expected as early as 2007.

Restrictions on imports from China impose higher costs on U.S. consumers, who now have to pay more for products. With the United States and other trading partners (for example, the European Union and Brazil) imposing or threatening to impose safeguards on Chinese apparel imports, in May 2005 the Chinese government responded by proposing export restrictions on the same products, thus "voluntarily" limiting their exports.

Figure 3: U.S. Balance on Current Account (Billions of Dollars)

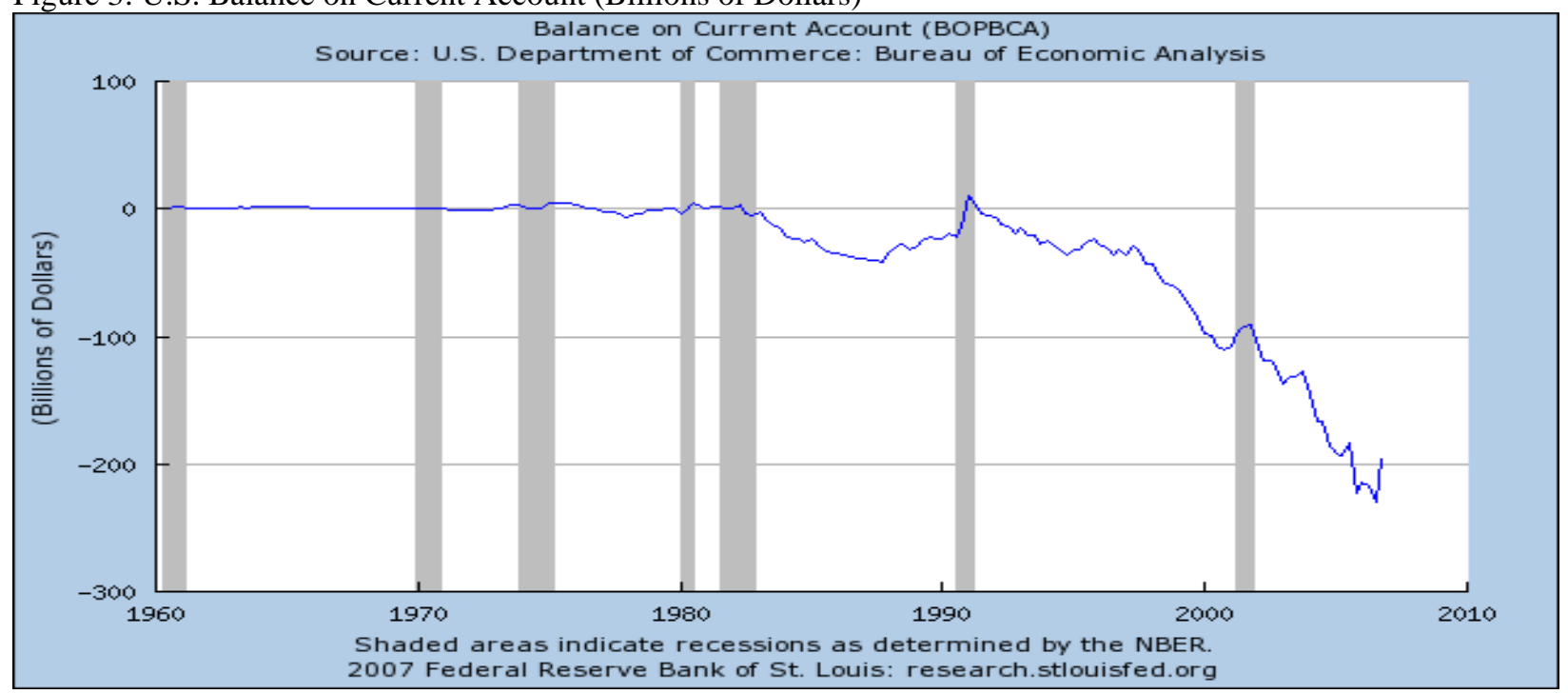

Source: U.S. Department of Commerce: Bureau of Economic Analysis 
The current state of global imbalance is unsustainable and calls for immediate actions to prevent the fall of the dollar, which could drastically affect not only the U.S., but the rest of the world as well. Moreover, the surge in oil prices and threats of terrorism and the ongoing war with Iraq are major challenges faced by the U.S. and the world as it struggles to fiscally reestablish itself.

Large drops in national savings with consequent drops in federal budget balance in recent years accounts for the increasing current account trade deficits. Tax-cuts that have been introduced by the U.S. government in order to counter the problem have led to a significant increase in private consumption and decrease in savings. This together with the rapidly increasing government expenditures mainly for defense purposes has led to record fiscal deficit.

The effects of fiscal policy on the current account balance remains unclear. Studies suggest that fiscal policy changes are a poor and costly (both internally and globally) way of reducing the current account deficits. The effects of an increase in government savings on the current account balance during a year of high productivity could be more than offset by increased consumption and drop of savings. Moreover, an inappropriate monetary policy can nullify the effects of a modified fiscal policy (Barth and Patricia, 2006).

Although there is an uncertainty regarding the appropriate fiscal policy that the government should adopt, the current fiscal state is unanimously considered to be a cause of concern (Barth and Patricia, 2006). Analysts predict that rigorous changes in fiscal policy by way of decreased government expenditure will indeed decrease the current account balance. But this will come at very high economic costs not only within the U.S. but in other parts of the world as well. Therefore, in the absence of policy changes to boost consumption in the emerging economies, the fiscal tightening will make little or no difference in bringing down the current account balance.

With the baby boomers approaching retirement, the government expenditure on their social security and medical care will further deteriorate the financial situation. The refusal of the White house to increase the taxes in the face of soaring costs in various sectors, has made the government's aim of cutting the budget deficit by half by 2009 an unrealistic dream.

The long-term interest rates were kept from increasing this far mainly due to the easy monetary policy, lack of complete understanding of the fiscal stance in U.S. by foreign investors and continuing support from foreign central banks. But if Japan and Europe continue to grow as expected and the foreign investors begin to loose confidence in the heavily indebted U.S., the era of American supremacy may soon come to an end with the possibility of the euro replacing the dollar as the international currency.

\section{Impact of the Euro}

Following the introduction of the euro in January 1999, there has been an increase in comovements in financial asset returns as a result of greater integration and economic interdependence between the economies of the European Union. According to the assessments of Cappiello, Hordahl, Kadareja and Manganelli, (2006), although the increase in co-movements 
has been more pronounced in the bond market, there has been reasonable increase in the equity market as well.

While most of the increase in co-movements in the equity market is due to the large member states of the euro area, both the large and small member economies in the euro area encountered significant increase in integration in the bond market. Moreover, the presence of "cross Atlantic factors" is more pronounced in the equity market; that is there has been an increase in comovements between the larger euro area economies and countries like the U.K. and U.S. after the introduction of the single currency. However, the degree of integration with other non-euro countries like Japan continues to be low in both the equity and bond markets.

With regard to the impact of the introduction of euro on asset pricing, a change in the term structure risk premia was observed. This change is a result of changes in the dynamic behavior of macroeconomic variables after the introduction of the euro and the changes in the market-priceof-risk factors. While, the average premia has remained the same as before, there has been a reduction in its variability because of smaller macroeconomic shocks after the launch of euro. However, the macroeconomic factors that best explained the variability of the premia continue to be important even after the introduction of the euro.

Figure 4: U.S. / Euro Foreign Exchange Rate (U.S. Dollars to One Euro)

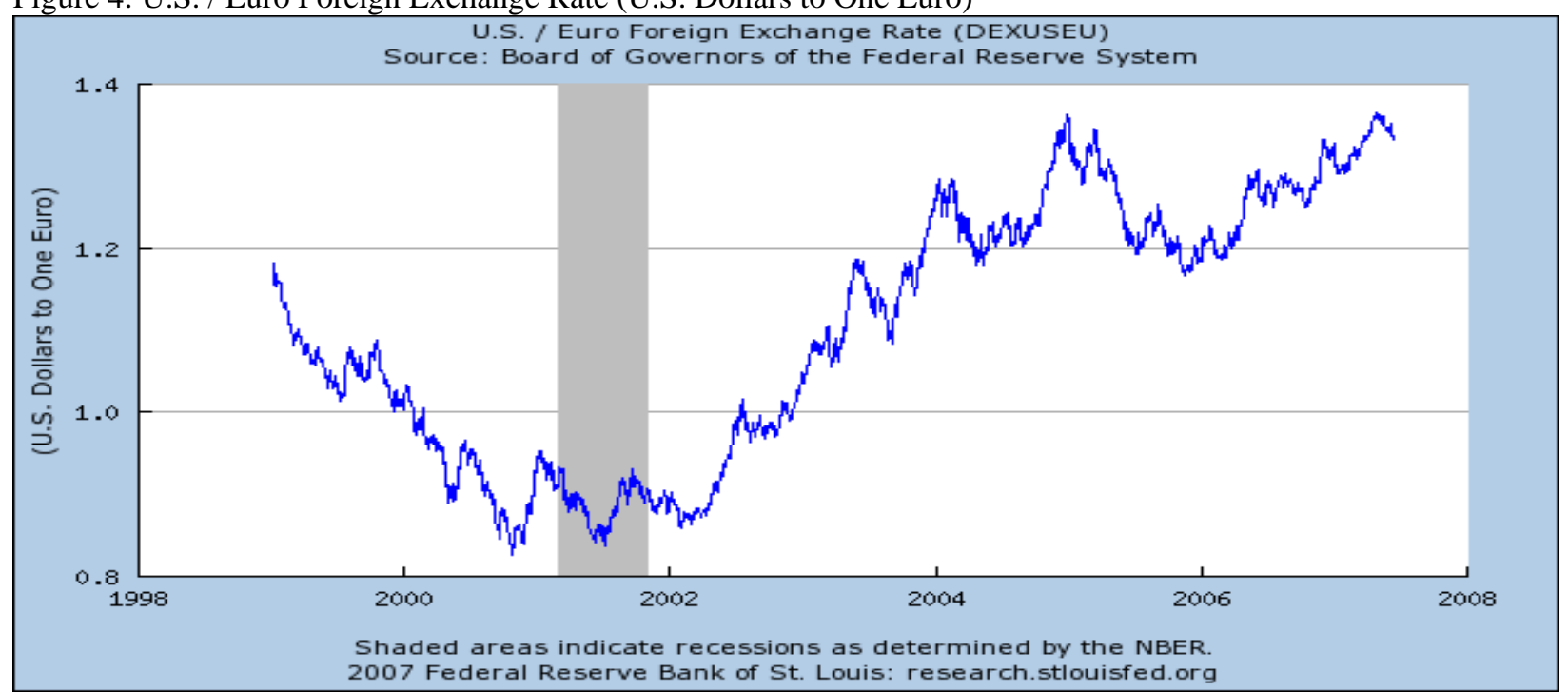

Source: Board of Governors of the Federal Reserve System

\section{The EU and the Role of Euro}

The European Union has recently expanded from 15 to 25 members. Bulgaria and Romania are expected to join in 2007. Those joined on May 2004 were: Cyprus, Czech Republic, Estonia, Hungary, Latvia, Lithuania, Malta, Poland, Slovakia and Slovenia. Croatia and Turkey have recently started negotiations. In December 2005, the European Council decided to grant candidate country status also to the Former Yugoslav Republic of Macedonia, with whom accession negotiations have not started yet. In order to join the Union, they need to fulfill the economic and political conditions known as the 'Copenhagen criteria', according to which a prospective member must: 
i. be a stable democracy, respecting human rights, the rule of law, and the protection of minorities

ii. have a functioning market economy; adopt the common rules, standards and policies that make up the body of EU law

The euro is the official currency of the EU. It was introduced to world financial markets in 1999 and launched as a currency in 2002. The euro is strongly advancing both economic and political integration between the participating EU member states. All EU member states are eligible to join if they comply with certain monetary requirements. The euro is managed and administered by the European Central Bank.

Outside Europe, the euro has been a success as well. Economists have studied the data from the euro's first few years in operation and found more of an increase in the supply of euro denominated assets outside of Europe than within the EMU.

About half of euro land trade with non-euro area residents is invoiced in the new currency. The euro's share in international debt securities has risen to above 30 percent. The euro's share of foreign exchange transactions reached one quarter in Continuous Linked Settlement data. Including forwards and swaps the dollar was involved in 89 percent of all transactions and the euro in 37 percent. In short the euro is the second international currency, after the dollar.

A high euro scenario would have many European countries joining EMU by the end of this decade. Most eager to join are the ten countries that joined EU in May 2004. Possibly Denmark, Sweden and U.K. will join the euro. In this case euro land exceeds the U.S. in income and trade. The key question is whether U.K. joins, because it would bring with it the London financial markets. By mid decade it did not look likely that Britain would join in the coming ten years. Real growth has been slower in Europe than United States for some years due to lower population growth. US monetary policy in the first part of the current decade was looser than ECB monetary policy.

All of the above developments are challenging the future leadership of the U.S. dollar as a global currency. In what follows we evaluate the intensity of the competition between the euro and the dollar.

\section{China}

Our discussion so far sheds light on the mounting trade and budget deficits of the U.S. and identifies Europe, China and Japan as its major contributors. While Japan and EU have flexible exchange rate regimes, China continues to maintain its exchange rate rigid in spite of growing pressure from the U.S. to appreciate the yuan. Although this alone cannot guarantee the restoration of global stability, it can help reduce U.S. deficits significantly as a result of a decrease in consumption of Chinese goods by the U.S.

According to Frankel (2004), such an enhancement in exchange rate flexibility is in China's own interests. The build up of foreign reserves in the emerging economies especially China took place after the Asian crisis of the 1990s in an effort to guard themselves from being hit by 
similar currency crises in future. However, China's present level of foreign reserves is too high causing an inflationary pressure on its economy. Moreover, in future, China will be better off investing domestically than continuing to accumulate foreign reserves, which has considerably low rate of returns. He also stresses on the need to act early in making reforms toward the much needed appreciation of the yuan while conditions are still favorable (high economic growth and trade surpluses) and the economy can withstand any unanticipated consequences from such exchange rate fluctuations. Today there are essentially three options for China:

i. Stick to its existing fixed exchange rate system, with the exchange rate close to yuan/dollar

ii. Liberalizing the currency similar to the appreciation of Japanese yen and euro

iii. Gradual adjustment toward a flexible exchange rate regime

Clearly, adopting a fixed exchange rate approach is unsustainable and will eventually lead to inflation. In addition, the growing tension with its trading partners (particularly U.S.) further accentuates the need for an appreciation of the renminbi, thus leaving China with remaining two alternatives to achieve this.

Meanwhile some economists including McKinnon (2005) argue that a change in the exchange rate flexibility cannot tackle the growing deficits problem of U.S. In fact, such changes can hit the Chinese economy hard resulting in a fall in economic growth and consequent deflation while U.S deficits continue to build up by way of imports from else where in Asia.

A significant appreciation can make China a less favorable place for investment for both domestic and global firms. In addition, the loss of value of dollar assets with respect to the domestic currency results in the decline of both consumption and investment. In effect, China would meet with a similar fate as Japan did when it saw a sudden decline of the yen following repeated appreciations in response to growing pressure from the U.S.

He further argues that the lack of savings in the U.S. is the main cause of the mounting deficits and hence an appreciation of the renminbi is not a solution to the global imbalance problem. Under a fixed exchange rate where employers don't fear changes in exchange rate, international adjustment is brought about by a natural increase in wages in the more productive economies. For e.g., China, by keeping its exchange rate fixed has had a 13\% increase in wage growth as compared to the U.S. with $2.7 \%$. This growth triggered among the skilled workers has influenced growth of wage rates of unskilled labor as well.

Also discussed is the possibility of China, in response to the growing international pressure making the yuan/dollar rate more flexible by restricting exchange rate changes to a narrow predefined controllable band. Such small changes in flexibility will not affect economic growth and the growth in wage rates will continue to resolve international differences in productivity and growth.

Many others feel that gradual macroeconomic adjustment is the best approach for China and other emerging nations. Gradual introduction of reforms which encourage more domestic consumption and investment along with an increase in savings in the U.S. can bring reductions in the trade deficits, hence improving the overall economic condition. Similar reforms in euro area countries have proved a success after a relatively slow and shaky start. 
To sum up, although the existing fear of the negative effects of a change to a flexible exchange rate is justifiable to a certain extent, the current levels are highly exaggerated. A very slow adjustment toward exchange rate flexibility approach is adopted by China, along with similar measures from other emerging nations can help solve the global imbalance issue. Glick (2005), Papademos (20060 and Rajan (2006) offer certain lessons from Europe's monetary integration that may be useful for Asian countries.

\section{Possible Future Scenarios}

Table 1 gives an account of the changes in the shares of the various major currencies in the total foreign currency reserves held over the years.

The dollar, which replaced the Pound sterling after the Second World War to become the hegemonic currency, continues to grow with a share of about $63.5 \%$ of the world's currency reserves. The substantial growth shown by the Japanese yen came to an end with the recession of the late 1990s. The deutsche mark was doing exceptionally well until it was replaced by the euro. Immediately after its introduction in 1999, the euro became the second major global currency with around 19.3 percent of the world's currency reserves held in euro by 2002.

Table 1: Reserve Currency Holdings (Original IMF data)

Share of National Currencies in Total Identified Official Holdings of Foreign Exchange, End of Year (in percent)

$\begin{array}{lrrrrrrrrr} & 1965 & 1973 & 1977 & 1982 & 1987 & 1992 & 1997 & 2002 \\ \text { All countries } & & & & & & & & \\ \text { U.S. dollar } & 56.1 & 64.5 & 76.2 & 57.9 & 53.9 & 48.9 & 59.1 & 63.5 \\ \text { Japanese yen } & 0.0 & 0.1 & 1.2 & 4.1 & 6.8 & 7.4 & 5.1 & 5.2 \\ \text { Pound sterling } & 20.0 & 4.2 & 1.5 & 1.8 & 1.9 & 2.6 & 3.3 & 4.4 \\ \text { Swiss franc } & 0.0 & 1.1 & 0.8 & 2.3 & 1.7 & 0.8 & 0.5 & 0.6 \\ \text { Euro } & 0.0 & 0.0 & 0.0 & 0.0 & 0.0 & 0.0 & 0.0 & 19.3 \\ \text { Deutsche mark } & 0.1 & 5.5 & 6.4 & 11.6 & 13.8 & 14.0 & 13.7 & 0.0 \\ \text { French franc } & 0.9 & 0.7 & 1.0 & 1.0 & 0.9 & 2.6 & 1.5 & 0.0 \\ \text { Netherlands guilder } & 0.0 & 0.5 & 0.4 & 1.0 & 1.2 & 0.7 & 0.5 & 0.0 \\ \text { ECUs } & 0.0 & 0.0 & 0.0 & 13.8 & 13.6 & 9.7 & 5.0 & 0.0 \\ \text { Unspecified currencies } & 22.9 & 23.6 & 12.3 & 6.5 & 6.4 & 13.3 & 11.3 & 7.1\end{array}$

As seen from Table 1, the three major global reserve currencies are the U.S. dollar, euro and the Japanese yen. In addition, all the key characteristics mentioned in Table 2 are quite favorable for these three economies. The unsustainable growing deficits of the U.S. on one hand and the recovery of the Japanese and euro area economies on the other, are posing a threat to the future prospects of the dollar as the international currency. With the recession in Japan hindering the growth of the yen, the real competition has now been reduced to one between the other two currencies namely the dollar and the euro. 
Table 2: Key Statistics for 2006

\begin{tabular}{|c|c|c|c|c|}
\hline $\begin{array}{l}\text { Countryl } \\
\text { Location } \\
\text { World }\end{array}$ & $\begin{array}{c}\text { Area } \\
\text { (sqkm) } \\
510.072 \text { million }\end{array}$ & $\begin{array}{l}\text { Population } \\
\text { (million) } \\
6,525\end{array}$ & $\begin{array}{l}\text { GDP(PPP) } \\
\text { (\$trillion) } \\
60.71\end{array}$ & $\begin{array}{c}\text { GDP-percapita(PPP) } \\
\mathbf{( \$ )} \\
9,500\end{array}$ \\
\hline USA & $9,631,420$ & 298 & 12.36 & 41,800 \\
\hline EU & $3,977,487$ & 460 & 11.72 & 25,480 \\
\hline NAFTA & $21,588,638$ & 430 & 12.89 & 29,942 \\
\hline ASEAN & $4,400,000$ & 553 & 2.17 & 4,044 \\
\hline UK & 244,820 & 60.6 & 1.83 & 30,300 \\
\hline Canada & $9,984,670$ & 33 & 1.114 & 34,000 \\
\hline Mexico & $1,972,550$ & 107 & 1.067 & 10,000 \\
\hline China & $9,596,960$ & 1,314 & 8.859 & 6,800 \\
\hline Japan & 377,835 & 127 & 4.018 & 31,500 \\
\hline India & $3,287,590$ & 1,095 & 3.611 & 3,300 \\
\hline Russia & $17,075,200$ & 143 & 1.589 & 11,100 \\
\hline
\end{tabular}

Source: CMF World Factbook 2006

So, how will the world economy take shape in the future? Four possible scenarios are discussed below.

Scenario 1: If the current trend of the dollar's decline and euro's appreciation continues, by 2020 the euro will equal the dollar and will further overtake it as the international currency. This is illustrated in Figure 5.

Figure 5: Disciplined Decline in the Dollar and Appreciation of the Euro at 10 percent annual rate

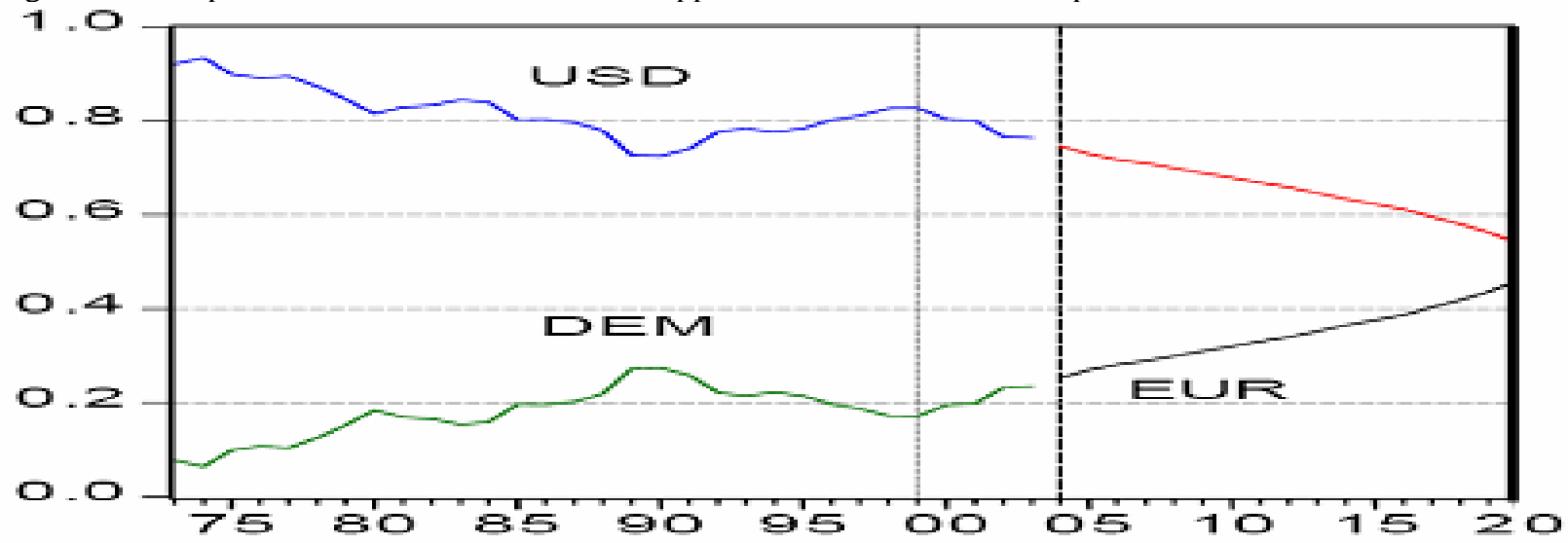

Source: Frankel and Chinn(2005) and Modified by the Authors

There are two alternate views on the persistence of the current situation, which are discussed in Bordo (2005).

Some fear a sudden inevitable readjustment will take place with a dramatic decline of dollar leading to drastic consequences in the U.S. as well as in the rest of the world. European and Japanese economies can expect a big hit as consumption for their goods in the U.S. will go down while China with its undervalued yuan will continue to do well. Moreover, it is anticipated that in such a situation, the emerging economies may switch from accumulating U.S. securities to accumulating euro thereby causing further dollar depreciation. 
The opposing view is one that expects a gradual and less harmful currency adjustment comparable to the one in the 1980's. The imbalances are traced to the accumulated savings of the aged in Japan and Europe and hence no threat to the U.S. securities held by the other economies is expected. Moreover, after the Asian crisis, the emerging economies have been building up dollar reserves to shield them from a future crisis. Bordo (2005) compares the present scenario with four historical episodes namely:

i. Prewar gold standard era, which saw a build up of surpluses and deficits and persistence of current account imbalance similar to the present day. The adjustment in this case happened gradually with transfer of capital from the surplus countries like Britian, Germany and France to the countries of the New World (Argentina, Australia, Canada). It followed the price specie flow mechanism of the classical gold standard.

ii. Interwar, where most of the countries adopted the gold exchange standard in which reserves were held in dollars, sterling and francs along with gold by U.S., Britain and France. Adjustments were not smooth and the system eventually collapsed.

iii. Bretton Woods, which was adopted after World War II and where the U.S, which had the largest gold reserves pegged dollar to gold making dollar the international reserve currency. Failure of U.S. to follow stable monetary and fiscal policies, the build up of dollars in Europe and Japan and the opposition of France to the system, lead to its collapse in 1973.

iv. 1977-1979, when the major countries of the world decided to adopt the system of managed floating exchange rates. But high inflation rates, along with the continued decline of the dollar, eventually led to change in the system.

His comparisons yield maximum similarity of the present scenario with the prewar gold standard scenario which had a benign outcome as opposed to the other four and expects a gradual and harmless change as had happened in the pre 1914 gold standard era due to similar levels of globalization and the continued relevance of the dollar as the international reserve currency.

In his paper, Edwards (2005) discusses the effects of a correction in the current account deficits of the U.S. He does so by analyzing several reversals of the past (1971-2001) and concludes that large and industrial countries had a decline in real exchange rate and high inflation and interest rates. In addition, there was a significant drop in GDP in the year of reversal which remained low for at least the next three years after which it picked up if the country's trade improved. He explains the decline in GDP growth following the U.S. current account deficit adjustment of 1987-1991 based on his analysis.

However, Edwards (2005) agrees that the U.S. presents a special case and might not incur such drastic consequences. The dollar being the international reserve currency, the possibility of the U.S. sustaining such deficits cannot be ruled out. But eventually, an adjustment is unavoidable.

With the growth of the world economy, the existence of a single successful hegemonic currency without eventually leading to global instability is highly unlikely. Scenarios 2, 3 and 4 discuss the consequences of more than one nation adopting a currency. 
Scenario 2: If the U.S. incorporates U.K. and perhaps NAFTA, then the rate of decline of the dollar may slow down or may even reverse. The red dotted curve in Figure 6 illustrates this.

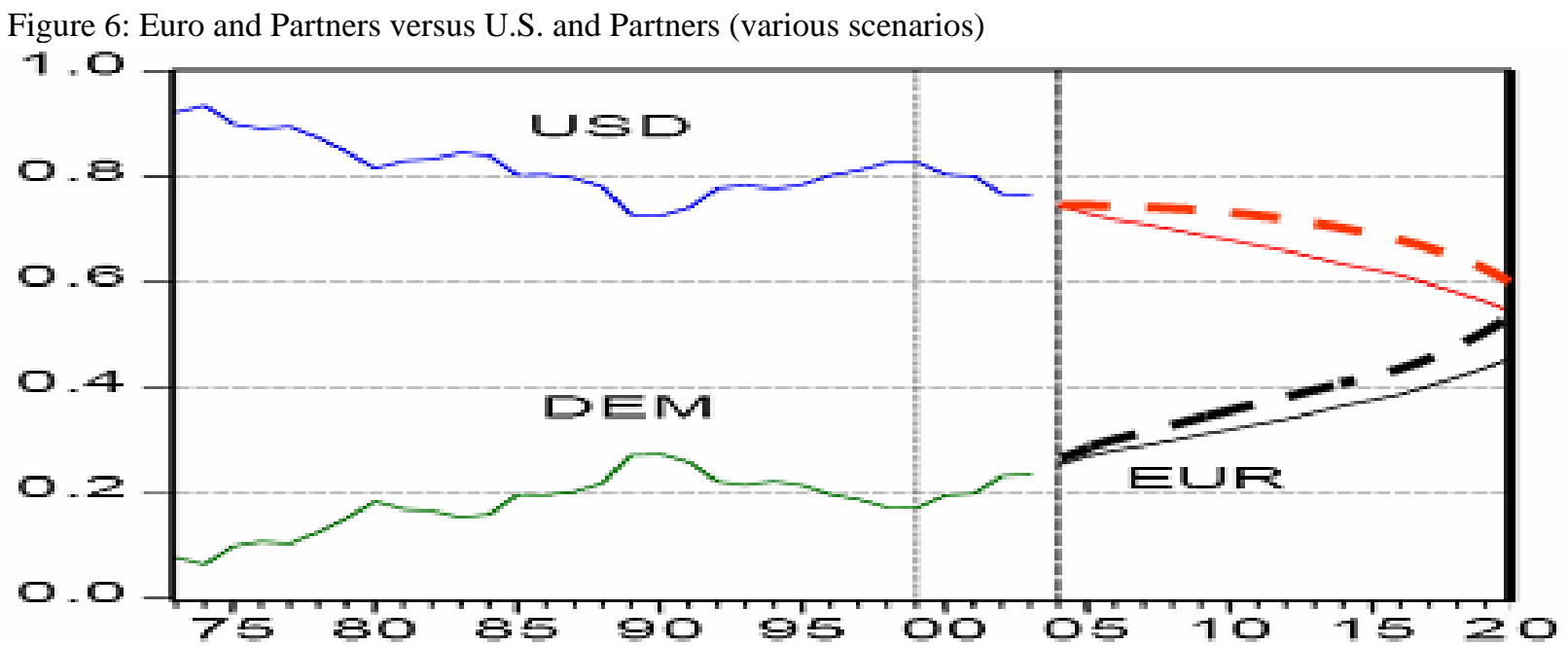

Source: Frankel and Chinn (2005) and Modified by the Authors

The North American Free Trade Agreement came into effect on the 1st of January, 1994 with the intention of removing most trade barriers and establishing free trade between U.S., Canada and Mexico, the three member countries. All three countries have benefited from the agreement especially Mexico which has seen a rapid economic growth and rise in employment since the NAFTA.

Following the crises in Mexico and Asia and the success of the euro, there has been much debate on the pros and cons of adopting a single currency by U.S., Canada and Mexico.

Two possible approaches to this goal have been identified; adoption of the U.S. dollar as the single common currency in the area (dollarisation) and the creation and adoption of a new currency (monetary integration).

Dollarisation has been mostly ruled out as it would mean loss of sovereignty over monetary policies, complete loss of seignorage revenue and lender-of-last-resort-facility for Canada and Mexico. Monetary integration on the other hand is much more viable. (Chriszt 2000)

Although, the benefits of such a monetary union by means of increased trade and stability of economies have been recognized, its occurrence in the near future is unlikely. Canada and Mexico continue to favor their flexible exchange rate system. In all three countries, the idea of replacing the current monetary system with a common central bank is yet to gain popularity. There are also growing concerns over matters like dominance, lender-of-last-resort and seignorage.

Yet another likely scenario is a monetary union involving the NAFTA and U.K. The lukewarm growth of the euro-area economies has resulted in U.K. not favoring a euro union. This along with excellent relations with U.S. and Canada has increased the prospects of a union with NAFTA. 
Such a union will prove to be much more successful that the EU and will in fact lead to the creation of a single largest common currency in the world.

Scenario 3: On the other hand, if U.K. and perhaps the 10 new members of the EU adopts the euro as its currency, there could be an even faster overtaking of the dollar by the euro as compared to Scenario 1. (Black dotted curve in Figure 6)

Figure 7: Fast Growers (real GDP growth, average percentage change 1950-97)

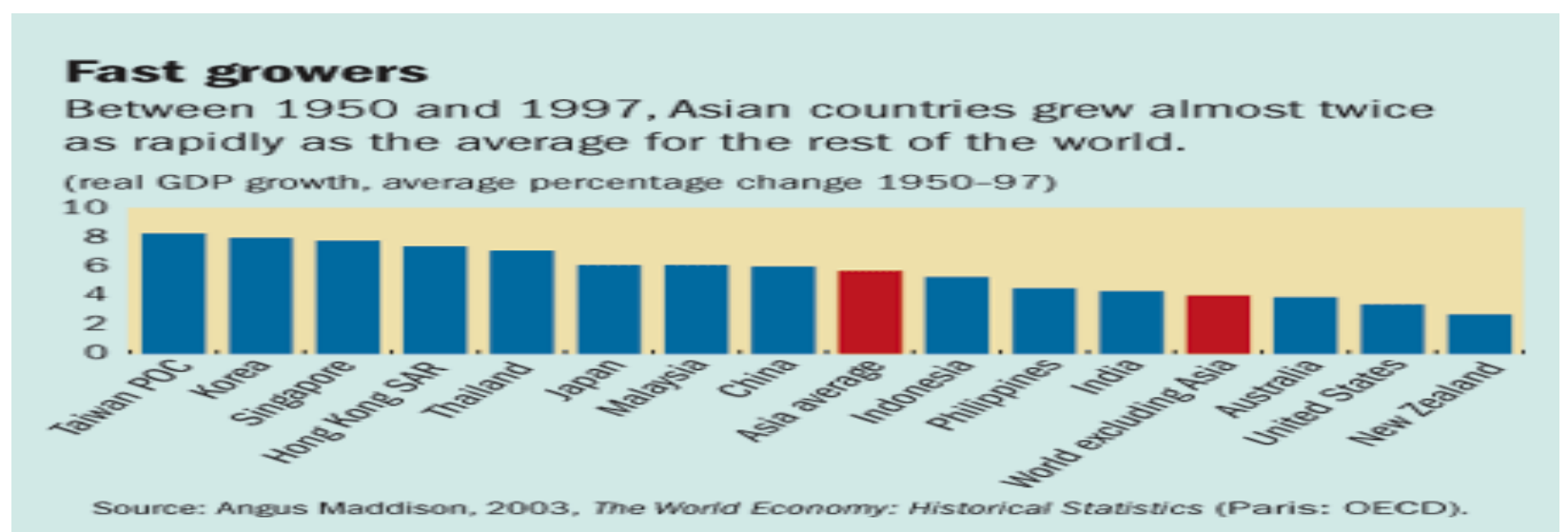

Source: Angus Maddision, 2003, The World Economy: Historical Statistics (Paris: OECD)

Scenario 4: With the success of the euro, prospects of a similar monetary union in Asia are high. This is especially true because of the presence of some of the largest and the fastest growing economies in the region (Figure 7). Such integration can give the area the much needed exchange rate stability, which can help prevent future crisis and enhance further economic growth in the region.

Japan's recovery after more than a decade of stagnation together with phenomenal and consistent economic growth in China(8\%) and India(6\%) are creating opportunities for increased integration in trade and investments benefiting not just these countries but the rest of Asia as well. In fact more than $50 \%$ of their foreign trade is with each other and ASEAN comparable to EU at $60 \%$ (see Figure 8), making east Asia an optimum currency area of the 21st century.

Figure 8: Intraregional trade (as share of total trade) 


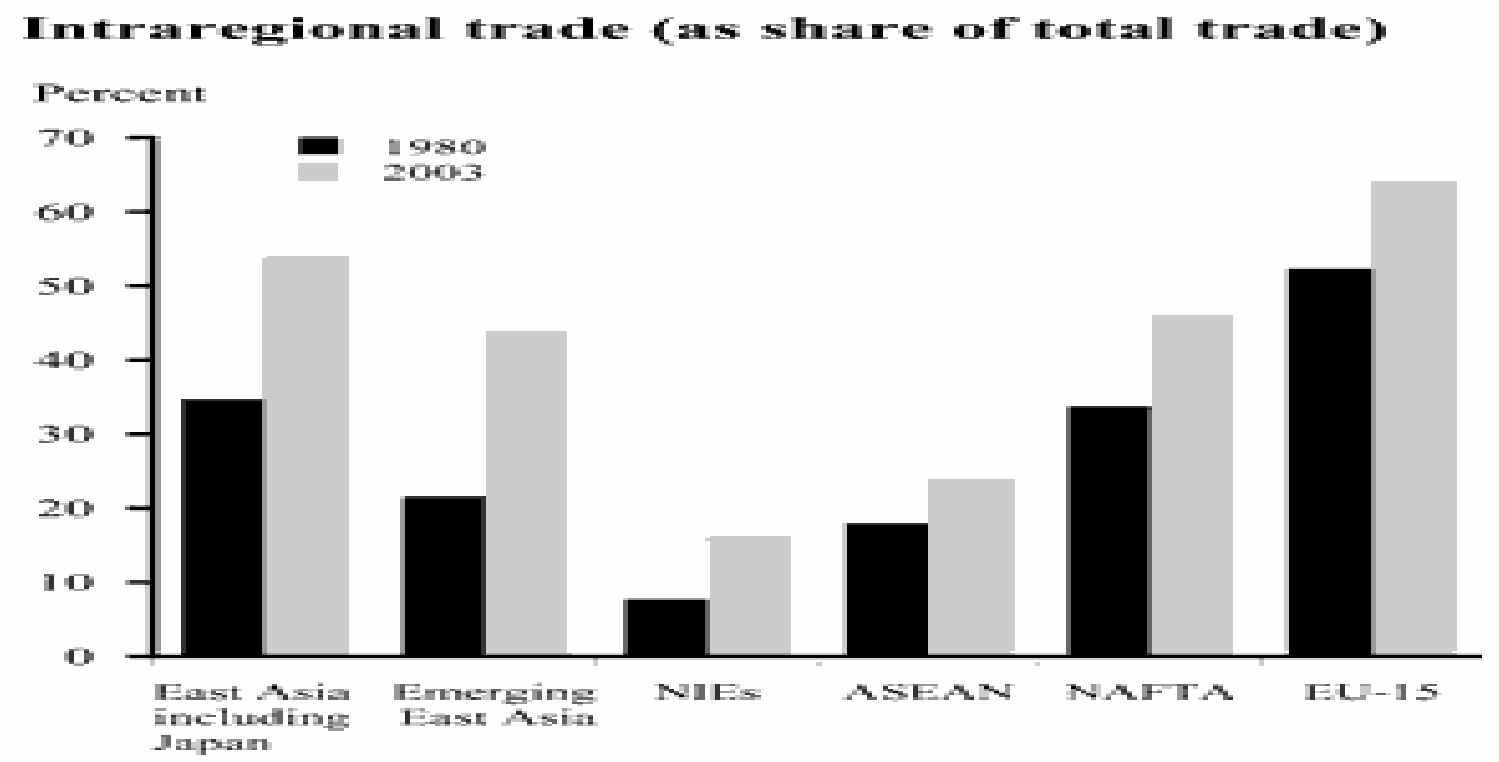

Source: FRBSF (2005)

However, in contrast to the EU there is a lack of political solidarity among the leading countries in Asia which is crucial for monetary integration to take place. Moreover, all Asian countries primarily depend on trade outside the region as opposed to European countries which were much more economically self contained. Although, there has been a significant increase in intra regional trade, it still involves mostly unfinished products and raw materials. Another factor differentiating the two regions is the absence of a stable and prominent currency like the Deutsche mark in the region. All this make the integration process a very distant prospect (FRBSF 2005).

According to Eichengreen (2006), a solution to this problem is the Parallel Currency Approach where he suggests the creation of an Asian Currency Unit (ACU) as a weighted average of the existing Asian currencies and to let it coexist alongside the different currencies in Asia. Not only does this eliminate the need for stabilizing the exchange rates of the individual currencies, it creates a stable currency that could be used in trade and investments within Asia. Such an approach will need less political solidarity until the ACU proves to be a success in the market indicating the readiness of the region for a monetary integration.

He further adds the need for the involvement of the central banks and governments of the participating countries to encourage the use of the ACU among the financial and non financial firms. This is because of the stiff competition faced by ACU from not only the national currencies but also the dollar, the most popular global reserve.

Some authors like Mundell (2002) recommend the use of the dollar as the parallel currency. However, with the growing integration and growth of trade among the countries in Asia and the prospects of a dollar decline can lead to the establishment of a single Asian currency. 


\section{Summary}

This paper argues that global economic development has progressed at a rapid rate during the last few years with the U.S. economy acting as the engine of growth since its brief recession in 2002. In contrast to global trade stability and growth, currency markets have experienced substantial volatility. The EU has chosen to overcome such volatility by establishing the European Monetary Union and introducing a common currency in 1999. The euro has been thus far a great monetary success and has continued and actually expanded the international significance of the German mark. The currently unsustainable balance of payments deficits in the U.S. have diminished the strength of the dollar and analysts are concerned about the future leadership of the dollar. We argue in this paper that at least three possible scenarios may develop. First, without any new membership in the EMU one may expect a disciplined decline of the dollar and a further strengthening of the euro. A second scenario involves the expansion of the U.S. to include the U.K. and also the NAFTA in a new Pan American Monetary Union. Such a development may stop the decline of the dollar or may actually reverse its current course and lead to its strengthening. The third scenario envisions the U.K. actually joining the EMU, which will result in a further increase in importance of the euro as a global currency. In addition, if the 10 new member states of the E.U. satisfy the convergence criteria and join, the euro could be strengthened further.

\section{Notes}

Bala Batavia is Professor of Economics at DePaul Universsity and can be reached at BBATAVIA@depaul.edu. A. G. Malliaris is the Walter F. Mullady Sr. Professor of Economics and Finance at Loyola University Chicago and can be reached at tmallia@luc.edu. They wish to thank Hiren Rokadia, Meril Joseph and Joko Mulyadi for research assistance.

\section{References}

Barth, M \& Patricia, P 2006, 'The Limits of Fiscal Policy in Current Account Adjustment', Occasional Paper No 2, Department of the Treasury, Office of International Affairs, April 2006.

Bordo, MD 2005, 'Historical Perspective on Global Imbalances’, Working Paper 11383, National Bureau of Economic Research.

Cappiello, L, Hordahl, P, Kadareja, A, Manganelli, S 2006, 'The Impact of the Euro on Financial Markets', Working Paper Series, no. 598, March 2006.

Chriszt, M 2000, 'Perspectives on a Potential North American Monetary Union', Economic Review, Federal Reserved Bank of Atlanta. Fourth Quarter, pp. 29-38.

Edwards, S 2005, 'The End of Large Current Account Deficits, 1970-2002: Are There Lessons for the United States?' Working Paper 11669, National Bureau of Economic Research.

Eichengreen, B 2006, ‘The Parallel Currency Approach to Asian Monetary Integration’, The American Economic Review, 96(2), pp. 432-436.

Fischer, S 2001, “Is the Bipolar View Correct?” Journal of Economic Perspectives, vol. 15, no. 2, pp. 3-24.

Frankel, J, Wei, SJ 2004, 'Managing Macroeconomic Crises: Policy Lessons Draft Chapter for Managing Volatility and Crises a Practitioner’s Guide’, March 2004. 
Frankel, J 2004, 'On the Renminbi: The Choice between Adjustment under a Fixed Exchange Rate and Adjustment under a Flexible Rate', Dalian Conference, China, May 26-27, 2004.

Frankel, J \& Chinn, M 2005, 'Will the Euro Eventually Surpass the Dollar as Leading International Reserve Currency?' NBER Conference, Newport, June 1-2, 2005.

Frankel, J, 2006, 'The Economic Outlook and the Twin Deficits', Boston Economic Club, May 24, 2006.

Glick, R 2005, 'Does Europe’s Path to Monetary Union Provide Lessons for East Asia?' Center for Pacific Basin Studies, Federal Reserved Bank of San Francisco, pp. 11-14.

Helbling, T 2005, Project Link Meeting, Research Department, International Monetary Fund, May 16.

International Monetary Fund, 2005, Global Financial Stability Report Market Developments and Issues, International Monetary Fund, April 2005.

International Monetary Fund, 2007, World Economic Outlook, International Monetary Fund, April 2007.

Kouparitsas, M 2005, 'Is the U.S. Current Account Sustainable?' Chicago Fed Letter, The Federal Reserve Bank of Chicago, no. 215, June 2005.

Krueger, OA 2005, ‘How Stable is the Global Economy?’ International Monetary Fund at the Stanford Institute for Economic Policy Research: Economic Summit, Stanford, California, February 11, 2005.

Malliaris, AG 2002, 'Global Monetary Instability: The Role of IMF, the EU and NAFTA', The North American Journal of Economics and Finance, vol. 13, pp. 72-92.

McKinnon, R 2005, Exchange Rate or Wage Changes in International Adjustment? Japan and China versus the United States, Stanford University, May 2005.

Mundell, R 2002, 'Does Asia Need a Common Currency?' Pacific Economic Review, vol. 7, pp. 3-12.

Papademos, L 2006, 'The Euro Area Economy and Emerging Asia - Current Issues and Policy Challenges', Speech at the Shanghai Head Office of People's Bank of China, Shanghai, February 2006.

Rajan, RG 2006, 'IMF in a Changing World, International Monetary Fund', Key Note Address at the International Conference on Global Asset Allocation, Arison School of Business, Israel.

Roubini, N \& Setser, B 2004, The U.S. as a Net Debtor: The Sustainability of the U.S. External Imbalances, New York University, Stern School of Business, Manuscript.

Salvatore, D 2005, 'Currency Misalignments and Trade Asymmetries among Major Economic Areas', The Journal of Economic Asymmetries, vol. 2, no. 1, pp. 1-24. 